\title{
KESADARAN HUKUM BERLALU LINTAS PADA PESERTA DIDIK KELAS XI SMK NEGERI 2 KOTA TERNATE
}

\author{
Rusdi Hasan ${ }^{1}$ dan Faisal $\left.\right|^{2}$ \\ ${ }^{1}$ Dosen Prodi Pendidikan Pancasila dan Kewarganegaraan, FKIP Universitas Khairun, Jl. Bandara Baabullah Akehuda Ternate \\ Utara, 97728, Indonesia \\ ${ }^{2}$ Dosen Hukum Pidana, Fakultas Hukum Universitas Khairun, Jl. Jusuf Abdurrachman Gambesi Ternate Selatan, Indonesia
}

Author Correspondence: rusdi_hasan@yahoo.com

$\begin{array}{ll}\text { Diterima } & : 02-03-2018 . \\ \text { Direvisi } & : 14-03-2018 \\ \text { Dipublikasi } & : 05-04-2018\end{array}$

Abstract. This study aims to determine the legal traffic awareness of first grade students of SMK Negeri 2 Kota Ternate. To find out the understanding or knowledge of students as an effort the traffic police can improve the discipline of motorized traffic. This research was conducted at SMK Negeri 2 Kota Ternate. This study used a qualitative approach with descriptive methods, with the number of respondents is15 students, among them the principal, vice principal of student affairs, vice principal of curriculum, PKN teachers and students. Data collection techniques use observation, in-depth interviews, and documentation. Data analysis in research using data reduction, data presentation, and conclusions. Based on the results of the study, there was a decrease in traffic law awareness. The results of the study showed that traffic legal legal awareness of class XI students of SMK Negeri 2 Ternate is still very low, this was caused because there were several inhibiting factors, among which it indicated that motorists in particular two wheels the whole has started in traffic discipline, is one of the alternative ways to increase legal awareness of traffic discipline of motorized motorbike traffic, especially two-wheeled riders. But in its implementation there are still obstacles faced by the Satlantas Ternate. Among other things, originating from the quality of students (community driving behavior) road arrangement and inadequate traffic signs.

Keywords: Legal awareness, student traffic, and SMK Negeri 2 Kota Ternate

\section{PENDAHULUAN}

Sekarang ini banyak pelajar belum cukup umur yang mengendarai kendaraan bermotor sendiri dan mereka belum mengetahui etika belalu luntas. Sehingga banyak kejadian kecelakan yang melibatkan pelajar dibawah usia. Yang seharusnya dalam Undang-Undang tertulis bahwa usia minimal untuk mengendarai kendaraan bermotor adalah 17 tahun. Ini dikarenakan pelajar di bawah usia 17 emosinya masih labil, lebih mementingkan egonya dan tidak mau mengalah. Ini sangat berbahaya apabila mereka berkendara, pasti akan ugal-ugalan, balapan dengan kendaraan lain hanya ingin dipuji.

Menurut Susenu 1987, Etika adalah suatu ilmu yang membahas tentang bagaimana dan mengapa kita mengikuti suatu ajaran moral tertentu atau bagaimana kita harus mengambil sikap yang bertanggung jawab berhadapan dengan pelbagai ajaran moral. Menurut Katsoff 1986, etika sebenarnya lebih banyak bersangkutan dengan prinsip-prinsip dasar pembenaran dalam hubungan tingkah laku manusia. Pengertian etika juga dikemukakan oleh Sumaryono (1995), menurut beliau etika berasal dati istilah Yunani ethos yang mempunyai arti adat-istiadat atau kebiasaan yang baik. Banyak pelajar di negeri ini yang tidak mengetahui etika-etika dalam berlalu lintas. Apabila ini terus berlanjut maka angka kecelakaan akan terus meningkat. Dengan demikian sangat diperlukan pengintegrasian pendidikan etika, berlalu lintas ke dalam kurikulum sekolah agar para peserta didik tau serta menerapkan etika berlalu lintas. Pemberian materi etika tidak hanya etika dalam kehidupan sehari-hari saja, akan tetapi penyampaian materi etika berlalu lintas juga sangat penting untuk keselamatan dalam berlalu lintas. Nasib bangsa kita ada ditangan generasi muda, dengan demikian diharapkan genersi bangsa kita lebih baik dan patuh terhadap hukum. 
Pengintegrasian pendidikan etika berlalu lintas dapat dimasukan dalam kurikulum Pendidikan Kewarganegaraan atau Karena etika berlalu lintas mencakup moral peserta didik. Penanaman etika tidak hanya dalam kewarganegaraan maupun agamanya saja, namun juga wajib mengetahui etika berlalu lintas. Diharapkan dengan pendidikan terus-menerus peserta didik dapat memahami serta mematuhi etika berlalu lintas. Sosialisasi/Pembelajaran etika tidak hanya di sekolah saja akan tetapi juga kepada publik Hal ini ditujukan agar masyarakat mengetahui etika berlalu lintas yang baik sehingga dapat memuat aturan cara mensosislisasikannya pada pelajar yaitu dengan cara integrasi kurikulum sekolah dengan materi disiplin lalu luntas.

Pendidikan keselamatan berlalu lintas tak henti-hentinya digalakan kepolisian. Guna mengingatkan dan menanamkan budaya keselamatan dalam berdisiplin berlalu-lintas, khususnya para peserta didik diminta untuk taat akan peraturan berlalu-lintas. Hal itu untuk menghindarkan para peserta didik dari kecelakaan dan pelanggaran hukum. "Langkah ini dilakukan dalam upaya meningkatkan kesadaran hukum para peserta didik dan menekan angka kecelakaan lalu-lintas," keselamatan berlalulintas dikalangan peserta didik ini merupakan upaya dalam memberikan pemahaman mengenai UU No. 22 tahun 2009 serta menanamkan kesadaran pentingnya mengutamakan keselamatan dalam berkendaraan. Sekaligus menanamkan kesadaran akan pentingnya keselamatan berkendara sejak dini secara otomatis akan menumbuhkan budaya disiplin berlalu-lintas."Rata-rata peserta didik masuk dalam usia rawan resiko kecelakaan lalu-lintas. Untuk itu, pembekalan mengenai kedisiplinan pun diberikan agar meningkatkan kesadaran para peserta didik terhadap pentingnya keselamatan berlalu lintas," pihak kepolisian menghimbau pihak sekolah dan orang tua peserta didik juga agar berperan aktif memberi pemahaman akan pentignya disiplin berlalu-lintas. "Para pihak sekolah dan orang tua murid hendaknya mengawasi anaknya agar tidak mengendarai kendaraan bermotor di jalan raya sebelum berusia 17 tahun dan memiliki SIM,"

Selain itu, untuk terus melakukan upaya-upaya menekan angka kecelakaan di Kota Ternate Provinsi Maluku Utara penindakan intens yang dilakukan demi menumbuhkan budaya disiplin berlalu lintas hingga pada akhirnya mampu menurunkan angka kecelakaan. Perkembangan lalu lintas di Indonesia semakin pesat dengan pertambahan jumlah kendaraan yang meningkat dari tahun ke tahun tidak seimbang dengan jumlah penduduk, volume jalan dan sarana penunjang lainnya, menyebabkan mobilitas masyarakat yang memiliki kepentingan yang beragam kadang sedikit terganggu dengan adanya gangguan lalu lintas. Gangguan yang terjadi dalam kehidupan berlalu lintas disebabkan oleh berbagai hal, baik disebabkan karena kurangnya sarana dan prasarana, maupun disiplin masyarakat yang terbilang rendah. Selain itu kurangnya kesadaran diri untuk menciptakan lingkungan yang tertib dan lancar.

Begitupun peserta didik yang terbilang memiliki andil besar dalam ketertiban dan kelancaran di masyarakat. Namun dilihat dari kenyataanya masih banyak perilaku peserta didik yang cukup mengganggu keamanan dan ketertiban lalu lintas hal ini disebabkan oleh kurangnya kesadaran diri untuk berdisiplin Penelitian ini membahas tentang kesadaran hukum berlalu lintas peserta didik kelas XI SMK Negeri 2 kota Ternate dalam menggunakan helm dan SIM. Berpijak dari uraian di atas maka perlu dilakukan penelitian untuk mengetahui pemahaman peserta didik tentang kesadaran hukum berlalu lintas.

\section{METODE PENELITIAN}

Untuk menghimpun data-data dan informasi sehubungan dengan penelitian ini, penulis menggunakan jenis penelitian kualitatif, yakni penelitian dimaksud untuk membuat pencandraan tentang situasi dan kondisi atau kejadian-kejadian yang terjadi di lapangan dengan tujuan untuk memberikan gambaran yang jelas, tentang kesadaran hukum berlalu lintas terhadap siswa SMK Negeri 2 Kota Ternate. Lokasi penelitian ini dilaksanakan di SMK Negeri 2 Kota Ternate sedangkan waktu penelitian dilaksanakan kurang lebih 2 bulan. Subjek dalam penelitian ini adalah orang-orang yang memiliki pengetahuan dan informasi tentang masalah atau fenomena yang akan diteliti di antaranya adalah: kepala sekolah, guru dan siswa SMK Negeri 2 Kota Ternate. 


\section{Tehnik pengumpulan dan Analisis Data}

Teknik pengumpulan data yang digunakan dalam penelitian ini adalah sebagai berikut; pertama, Observasi (pengamatan). Observasi adalah cara atau teknik pengumpulan data dengan melakukan pengamatan dan pencatatan secara sistematik terhadap gejala atau fenomena yang ada pada ojek penelitian (Moh. Pabundu Tika, 2006:68). Langkah pertama, penulis mengumpulkan data, melakukan pengamatan, dan mencatat terhadap gejala yang ada pada objek penelitian secara langsung yang berhubungan dengan kesadaran hukum berlalu lintas terhadap siswa SMK Negeri 2 Kota Ternate. Tahap kedua, dilakukan Interview (wawancara), yakni alat pembuktian terhadap informasi ataupun keterangan yang diperoleh sebelumnya. Teknik wawancara yang digunakan dalam penelitian ini adalah wawancara secara mendalam. Wawancara mendalam adalah proses memperoleh informasi dari informasi atau responden. Dalam penelitian ini wawancara yang dilakukan yaitu dengan guru dan siswa-siswi. Tahap Ketiga, adalah Dokumentasi. Dokumentasi adalah sumber informasi yang berhubungan dengan dukumen pada dasarnya adalah segala bentuk informasi yang berhubungan dengan dokumen baik yang resmi maupun yang tidak resmi, dalam bentuk laporan statistik, surat resmi, dalam bentuk harian dan semacamnya, baik yang diterbitkan maupun tidak (Muh.Ali, 2007: 14). Sementara analisis yang digunakan dalam penelitian ini adalah menggunakan teknik Analisis data kualitatif. Penggunaan teknik analisis ini dimaksudkan untuk mengetahui peran kepolisian dalam memberikan pemahaman tentang kesadaran hukum berlalu lintas kepada siswa-siswi SMK Negeri 2 Kota Ternate. Setelah itu akan ditarik kesimpulannya berdasarkan hasil analisis (Bogdan dan Biklen, 1990).

\section{HASIL DAN PEMBAHASAN}

\section{Upaya Sekolah Mengatasi Angka Kecelakaan Lalu Lintas}

Dari hasil wawancara kepala sekolah, guru dan siswa SMK Negeri 2 Kota Ternate, bahwa kesadaran hukum merupakan salah satu ciri bahwa masyarakat telah memahami dan mengerti hukum. Kesadaran hukum warga negara dapat terlihat dari perilaku di mana dia berada. Kesadaran hukum adalah kesadaran yang ada pada setiap manusia tentang apa hukum itu atau apa seharusnya hukum itu, suatu kategori tertentu dari hidup kejiwaan kita dengan mana kita membedakan antara hukum dan tidak hukum (onrecht), antara yang seyogyanya dilakukan dan tidak seyogyanya dilakukan (Scholten, 1954: 166). Sedangkan menurut Krabbe mengatakan bahwa sumber segala hukum adalah kesadaran hukum (V. Apeldoorn, 1954: 9). Kesadaran hukum mempunyai beberapa konsepsi, salah satunya konsepsi mengenai kebudayaan hukum. Konsepsi ini mengandung ajaran-ajaran kesadaran hukum lebih banyak mempermasalahkan kesadaran hukum yang dianggap sebagai mediator antara hukum dengan perilaku manusia, baik secara individual maupun kolektif (Soerjono, Soekanto, 1987,hlm. 217).

Aturan lalu lintas sebenarnya tidak hanya berwujud larangan tetapi juga berbentuk perintah, dilarang belok, dilarang parkir, dilarang menyalip atau dilarang berputar. Peraturan tersebut sebenarnya banyak sekali bisa berbentuk perintah, petunjuk, dan pemberitahuan karena wujud dari peraturan sebenarnya banyak sekali. Permasalahan di sini adalah karena kurangnya kesadaran dari masyarakat terutama remaja. Bentuk dari kurangnya kesadaran itu adalah pelanggaran.Banyak peraturan dan hukum yang telah menetapkan tetapi remaja yang bersikap tak acuh nekat melanggar begitu saja atau sudah tahu tetapi tetap melanggar. Banyak kejadian kecelakaan yang disebabkan karena perilaku remaja yang seenaknya sendiri berkendara tanpa mengindahkan tata tertib.

Dari hasil pengamatan bahwa anak-anak remaja banyak yang menganggap apabila berkendara dengan mematuhi tata tertib lalu lintas dianggap kolot padahal sebenarnya mereka tidak berpikir luas dan kedepan akan bahaya dan dampak yang akan dialami apabila melanggar lalu lintas. Karena, sejatinya peraturan dibuat untuk ditaati bukan dilanggar. Namun, paradigma masyarakat yang salah kaprah memutar balikkan slogan sehingga menjadi doktrin dan kemudian membudaya menjadi watak yang sulit untuk dirubah, yaitu "Aturan dibuat untuk dilanggar". 
Paradigma dan pemikiran masyarakat sudah sangat salah kaprah, mereka menganggap bahwa peraturan tidak penting untuk ditaati. Selain itu, lemahnya hukum dan ketidak bijaksanaan aparat pemerintah sendiri yang membuat masyarakat melunakkan segala hukum dan peraturan yang sudah ditegakkan. Banyak masyarakat percaya bahwa aparat polisi bisa disuap, dll. Karena, ketidakbijaksanaan polisi sendiri seakan pemerintah membuat aturan dan itu dijadikan lahan keuangan bagi oknum-oknum nakal. Saat kepercayaan masyarakat pada aparat pemerintah telah pudar, maka pelanggaran tata tertib mulai merajalela. Banyak remaja berkendara nekat melanggar peraturan tata tertib berkendara karena hal tersebut, sehingga dalam melestarikan tata tertib berkendara diperlukan kerjasama antara semua pihak demi terwujudnya budaya tertib berlalu lintas.

Kendaraan digunakan oleh pengemudi mempunyai karakteristik yang berkaitan dengan kecepatan, percepatan, perlambatan, dimensi dan muatan yang membutuhkan ruang lalu lintas yang secukupnya untuk bisa bermanuver dalam lalu lintas jalan merupakan lintasan yang direncanakan untuk dilalui kendaraan bermotor maupun kendaraan tidak bermotor termasuk pejalan kaki. Jalan tersebut direncanakan untuk mampu mengalirkan aliran lalu lintas dengan lancar dan mampu mendukung beban muatan sumbu kendaraan serta aman, sehingga dapat meredam angka kecelakaan lalu lintas.

\section{Kesadaran Berlalulintas Dalam Perspektif Pendidikan Kewarganegaraan}

Dari hasil pengamatan dan wawancara bahwa lalu lintas adalah merupakan gerak lintas manusia dan atau barang dengan menggunakan barang atau ruang di darat, baik dengan alat gerak ataupun kegiatan lalu lintas dan jalan yang dapat menimbulkan permasalahan seperti terjadinya kecelakaan dan kemacetan lalu lintas. Oleh kerena itu, lalu lintas selalu identik pula dengan penerapan tata tertib bermotor dalam menggunakan jalan raya dengan demikian maka pelanggaran lalu lintas adalah pengabaian terhadap tata tertib lalu lintas yang dilakukan oleh pengguna kendaraan bermotor yang menimbulkan kecelakaan lalu lintas bagi pengguna jalan lainnya baik hilangnya nyawa maupun lukaluka.

Secara umum ada tiga komponen terjadinya lalu lintas, yaitu manusia sebagai pengguna, kendaraan dan jalan yang saling berinteraksi dalam pergerakan kendaraan yang memenuhi persyaratan kelaikan dikemudikan oleh pengemudi mengikuti aturan lalu lintas yang ditetapkan berdasarkan peraturan perundangan yang menyangkut lalu lintas dan angkutan jalan melalui jalan yang memenuhi persyaratan geometrik. Manusia sebagai pengguna dapat berperan sebagai pengemudi atau pejalan kaki yang dalam keadaan normal mempunyai kemampuan dan kesiagaan yang berbeda-beda (waktu reaksi, konsentrasi, dll). Perbedaan-perbedaan tersebut masih dipengaruhi oleh keadaan fisik dan psikologi, umur serta jenis kelamin dan pengaruh-pengaruh luar seperti cuaca, penerangan / lampu jalan dan tata ruang. Dalam UU No. 22 Tahun 2009 didefenisikan sebagai gerak kendaraan dan orang di ruang lalu lintas jalan, sedangkan yang dimaksud dengan ruang lalu lintas adalah prasarana yang diperuntukkan bagi gerak pindah kendaraan, orang, atau barang yang berupa jalan dan fasilitas pendukung. Adapun defenisi mengenai lalu lintas menurut Djajoesman (1976:50) bahwa secara harfiah lalu lintas diartikan sebagai gerak (bolak balik) manusia atau barang dari satu tempat ketempat lainnya dengan menggunakan sarana jalan umum.

Berdasarkan data yang didapatkan ketika peneliti dari hasil pengamatan dan wawancara bahwa Pendidikan Kewarganegaraan adalah mata pelajaran yang secara umum bertujuan untuk mengembangkan potensi individu warga negara Indonesia, sehingga memiliki wawasan, sikap, dan keterampilan kewarganegaraan yang memadai dan memungkinkan untuk berpartisipasi secara cerdas dan bertanggung jawab dalam berbagai kehidupan bermasyarakat, berbangsa dan bernegara .

Berdasarkan pendapat di atas jelas bagi kita bahwa PKn bertujuan mengembangkan potensi individu warga Negara baik itu di bidang politik dengan cara berpartisipasi politik yang aktif. Dengan demikian maka warga Negara haruslah menjadi warga yang berkualitas dan profesional, sebab jika warga tidak berkualitas tentu tujuan PKn itu sendiri tidak tercapai. 
Berdasarkan uraian di atas peneliti berpendapat bahwa dalam pengetahuan PKn, seorang warga masyarakat harus memiliki pengetahuan kewarganegaraan, serta harus berkembang sikap, keterampilan dan nilai-nilai. Sesuai dengan Depdiknas (Sudrajat, 2005: 33) yang menyatakan bahwa tujuan PKn untuk setiap jenjang pendidikan yaitu mengembangkan kecerdasan warga negara yang diwujudkan melalui pemahaman, keterampilan sosial dan intelektual, serta berprestasi dalam memecahkan masalah di lingkungannya. Untuk mencapai tujuan PKn tersebut, maka kita sebagai generasi penerus bangsa berupaya melalui kualitas pembelajaran Pkn, agar upaya ini bisa dicapai jika kita siap memberikan pemahaman tentang pengetahuan kewarganegaraan kepada masyarakat sehingga pada saat pesta demokrasi itu berlangsung dikemudian hari masyarakat tidak lagi kebingungan dengan memilih pilihan mereka.

Dalam dimensi ini warga masyarakat diajak untuk berperan penting untuk mewujudkan sebuah komitmenitas misalnya dalam mewujudkan masyarakat madani (civil society), keterampilan mempengaruhi dan memonitoring jalannya pemerintahan, dan proses pengambilan keputusan politik, keterampilan memecahkan masalah sosial, keterampilan mengadakan koalisi, kerja sama, dan mengelola konflik. Jika dikomparatifkan dengan kondisi secara realitas dinamika sosial politik yang terjadi pada saat pesta demokrasi itu berjalan baik itu berkaitan dengan jalannya pemerintahan atau proses pengambilan keputusan bahkan ketrampilan mengadakan koalisi maka akan kita temukan yang namanya sikap kekeliruan yang dilakukan oleh sekolompok manusia, artinya sebuah sikap yang di tampilkan oleh para pihak kepolisian itu mencerminkan sikap yang tidak sesui dengan komponen dasar pendidkan kewarganegaraan yaitu keterampilan. Sebuah keterampilan berpartisipasi dalam politik tidak menonjol dengan maksimal baik itu para kontestan maupun masyarakat. Bukan karena sebuah keterdesakan kebutuhan ekonomi akan tetapi kurangnya pengetahuan dan keterampilan kewarganegaraan yang meliputi monitoring jalannya pemerintah, membentuk masyarakat madani, keterampilan memecahkan masalah serta kerja sama dan mengelola konflik secara bersamaan, mencakup antara lain percaya diri, penguasaan atas nilai religius, norma dan moral luhur nilai keadilan, demokratis, toleransi, kebebasan individual, kebebasan berbicara, kebebasan pers, kebebasan berserikat dan berkumpul, dan perlindungan terhadap minoritas (Sudjana, 2003 ). Sebuah titik kejelasan dari demensi nilai nilai kewarganegaraan yang terhimpun diatas maka kita bisa berbicara tentang realitas maka dari beberapa komponen misalkan percaya diri, demokratis, serta moral bahkan keadilan jarang dimiliki oleh para pihak kepolisian karna berbicara soal konsep keadilan maka sikap yang ditampilkan tidak mencerminkan suatu sikap adil, bahkan sebaliknya jika dikaji dari segi moral, percaya diri serta demokratis tidak membuktikan. Hal ini dibuktikan lewat pengetahuan kewarganegaraan (civics knowledge) dan keterampilan kewarganegaraan (civics skills) akan menjadi seorang warga negara yang berkompeten.

Warga negara yang memahami dan menguasai pengetahuan kewarganegaraan (civics knowledge) serta nilai-nilai kewarganegaraan (civics values) akan menjadi seorang warga negara yang memiliki rasa percaya diri, sedangkan warga negara yang telah memahami dan menguasai keterampilan kewarganegaraan (civics skills) serta nilai-nilai kewarganegaraan (civics values) akan menjadi seorang warga negara yang memiliki komitmen kuat.

\section{KESIMPULAN}

Berdasarkan hasil dan pembahasan yang penelitian paparkan diatas maka dengan kesimpulan sebagai berikut. Dari penelitian yang telah peneliti lakukan maka dapat disimpulkan bahwa ada pengaruh antara tingkat pemahaman tentang kesadaran hukum berlalu lintas berkendara yang aman terhadap ketertiban berlalu lintas di kalangan pelajar. Di mana dari hasil tabulasi silang yang telah dilakukan dapat diketahui bahwa sebagian besar responden yang menyatakan tingkat kesadaran berkendara yang cukup baik berdampak pada perilaku tertib berlalulintas yang cukup baik pula dengan prosentase sehingga dari penelitian ini dapat diketahui adanya korelasi positif antara tingkat kesadaran berkendara yang aman dengan perilaku tertib berlalulintas yang ditunjukkan dengan persentase. Oleh karena itu diharapkan agar sertiap anggota masyarakat khususnya pelajar dapat lebih memahami, menyadari, serta menerapkan cara berkendara yang aman agar tercipta kondisi lalulintas yang tertib dan aman. 
Rusdi Hasan dan Faisal. 2018. Legal awareness, student traffic, and SMK Negeri 2 Kota Ternate

Kepolisian dan instansi yang terkait dapat lebih menggencarkan sosialisasi program safety riding sebagai upaya meningkatkan kesadaran aman berlalulintas, sehingga dapat menekan angka kecelakaan dan menegakkan ketertiban di jalan raya.

\section{DAFTAR PUSTAKA}

Rinto Raharjo. (2014). Tertib Berlalu Lintas. Shafa Media: Yogyakarta.

Suharso dan Retnoningsih. (2005). Lalu Lintas dan angkutan jalan,Indonesia Legal Center Publishing: Jakarta. Soerjono, Soekanto. (1975). Lalu Lintas dan angkutan jalan tentang kendaraan. Kesindo utama: Surabaya. (1990). Polisi dan Lalu Lintas (Analisis menurut sosiologi hukum). Bandung: Mandar Maju.

Scholten. (2008), Tentang kedaran Hukum dalam Berkendaraan. Yogyakarta: Penerbit New Merah.

Undang-Undang RI Nomor 14 Tahun 1992, Tentang Lalu Lintas dan Angkutan Jalan

Undang-Undang RI nomor 22 Tahun 2009, Tentang Lalu Lintas dan Angkutan Jalan 